\title{
THE DEVELOPMENT OF PRIVATE SECURITY AND THE DILEMMAS SURROUNDING THE EFFECTS OF PRIVATE SECURITY SERVICES
}

\author{
Zorica Saltirovska, PhD \\ Institute for Security, Defence and Peace \\ E-mail: zorica_ind@yahoo.com
}

\begin{abstract}
Despite the fact that private security services are not a new phenomenon, the increased trend in the development of private security is linked to the 1990s, when the number of private security service providers saw a manifold increase. Along with the increase, the variety of services also increased, which in turn created the need for these providers to be categorized based on the type of service they provide. One of the most esteemed authors in this area, Peter Singer (Singer, 2007), points out the fact that the development of private security has gone too far in an overly short period, while the services of private security companies are being used by affluent individuals, companies, non-governmental organizations, countries, regional, and international organizations. However, the development in the scope of the private security sector is only one of the many aspects that need to be taken into consideration when it comes to its dynamic expansion. Other aspects, such as the quality, utility, and the effects of its services, need to be inserted into the equation, especially since experience has inspired controversial attitudes and opinions. This paper focuses on the tendencies relative to the development of private security, and the issue of the effects that private security services exert on the security of citizens, not only on a national, but also on international level.
\end{abstract}

Keywords: private security, private security services, development, effects 


\section{Secuurity}

\section{Introduction}

Whenever we speak of security, we think about a secure environment where people can realize their goals without impediments and without fearing for their life or wellbeing. Security is closely linked to society, which is a volatile category - a fact that inevitably leads to the adaptability and further development of the concept of security. Technology and modern security challenges have caused drastic changes in the security sphere, where great and powerful military forces are not always compatible to perform specific, short-term, limited military and security operations. It is becoming increasingly more common for professionals to be hired from private security organizations and associations to perform these operations. This widespread use of private security services has initiated a string of debates as to the positive and negative effects of such services, leading to a large number of controversial, discrepant conclusions. The only unequivocal conclusion is that there is a palpable need for a comprehensive analysis of the causes of the development of the private security sector, as well as of the effects of the use of its services.

\section{Defining the causes of the development of private security}

Private security is most often spoken of as security that can be procured on the market, meaning that an increased demand will result in an increased supply and, consequently, in an increase in the number of private security companies and the specter of their services, and vice versa. As a result, we can conclude that the increased demand is the crucial factor that generated the enormous rise of this industry since the last decade of the $20^{\text {th }}$ century. This conclusion solicits another question: what was it that increased this demand at a time when the armed forces of almost every country are perfectly or soundly structured, organized, and armed to perform their tasks? The Westphalia Peace Treaty charted the responsibility of the state in the protection of its citizens, so now the question of the state's monopoly over the use of force and control of violence must invariably be posed. Was stateprovided protection insufficient or inadequate, or were there other factors that contributed to the development of the private security sector, which overtook roles that have been under the control of states for centuries?

Mercenaries and private armies have existed since the first wars. In cases of lack of physical or other power of the states, communities, or individuals to protect their estates or territories, or win a battle, they would rent out private armies. Feudal lords complemented their armies with paid soldiers. Even the founding of countries and the Westphalia Peace 


\section{Seccuritity}

Treaty did not put an immediate end to the market distribution of power and violence. In the $17^{\text {th }}$ and $18^{\text {th }}$ centuries, many private armies were delegated and engaged for greater distances (the Netherlands, England, France, and Portugal) or to augment state power (France). These powers were at the same time army forces, police forces, and security forces - to protect trade routes and non-military territories, and they served the government with which they signed the treaty. Modern $21^{\text {st }}$ century countries also employed private security services, mostly for logistical support and arms procurement. During the Cold War, the USA rented forces to perform military trainings, whereas the government of the UK used the US market of military services, but allowed its citizens to sell their military services to other countries. Because this market distribution of security was condemned by the public and the international factor, private military services were secret and informal (Avant, in Williams, 2008:447).

The end of the $20^{\text {th }}$ century initiated a string of global changes that influenced the concept of national and international security. These changes created conditions for a gradual yet active transfer of traditional security roles from the state to the private security sector that achieved a certain level of international recognition. The modern private security companies have a corporate structure and are relatively open to the public (with its own web pages, employment lists, price lists, etc.), - all of which increases the widespread use of private security services.

The analysis of changes in the international community from the end of the $20^{\text {th }}$ century points to several significant moments as preconditions to the development of private security, and increased the demand for private security services:

- The end of the Cold War also put an end to the bipolarization of the world, practically eradicating the widespread fear of a great war that would endanger national interests; this change influenced the way countries (not only developed countries, but also those in transition) felt about security in the $21^{\text {st }}$ century. The great powers became more sensitive to their own war losses (especially the loss of human lives) in operations outside national borders (Bunker, 2003:58), and the accountability of governments increased due to public pressure. Taking into consideration that governments are entrusted with the primary responsibility of protecting the interests of their own citizens, government interest in participating in peace missions to remote parts of the world decreased (Mandel, 2001:2), and professionals from private military companies were increasingly engaged. On the other hand, since the possibility of an external attack in these countries became less likely after the end of the Cold War, governments cut their armed forces down to a maximally efficient level; this precipitated significant unemployment rates among army personnel, who were then 


\section{Securiatity}

eligible for employment in the private security sector. Transition countries lost the support found in the formerly powerful Warsaw pact and therefore diverted their policies towards joining the Western countries' organizations - NATO and the EU. In view of meeting the membership criteria, they had to cut down and professionalize their armies, which resulted in an increase of the demand for and supply of eligible ex-army personnel for hiring. This is one of the reasons for the fast growth of the private security sector during the last decade of the $20^{\text {th }}$ century.

- The privatization process engulfed the countries in transition, even those that had a monopoly in all areas (Schreier and Caparini, 2005:86). Private alternatives became apparent and attractive for people, and the attitude was transferred in the area of security, where the private offers increased. After almost 400 years, the state and its security institutions were no longer the sole subjects accountable for the citizens' safety. The Westphalia system is slowly being replaced by a more flexible, though more complicated, private security system. Theoretically, this leaves space for countries to perform the most vital tasks, leaving the simpler ones to the private security sector, allowing for a commercial profit (Richards and Smith, 2007:3-5).

- Immediately after the end of the Cold War, the weaknesses of many countries became a more evident impediment to their ability of ensuring the safety of their citizens, which was now endangered by the surge of smaller, mainly internal conflicts, new challenges, risks and threats. The non-functionality of the state structures and forces during the transition processes, as well as the withdrawn support and protection previously offered by the great powers, resulted in the surfacing of all the flaws and difficulties in the functioning of these countries' armies - corruption, ethnic rivalry, poor standards, etc. - all of which resulted in an increased potential for violence. The feeble governments opened the way for international criminal groups, rebels, and para-military forces, which further undermined order and disrupted global norms (Avant, in Williams, 2008:449). The lack of efficiency and power of the post-conflict countries and their military forces to respond to new threats and challenges to the safety, the lack of trained personnel, the overly high maintenance price of an efficient military force and, in general, the poor state of affairs in these countries, gave rise to an opportunity for private security companies to fill in the void. In fact, these companies aided frail governments in developing their security capacities, and some countries that cannot afford maintaining a regular efficient army force, see these companies as the only real option and the most attractive alternative (Bunker, 2003:59). 


\section{Seccurity}

- Humanitarian organizations in conflict or crisis areas are faced with recurring hostage incidents, threats, violence, and murders. According to research conducted in 1998, the number of victims employed by the Red Cross in different positions was greater than the number of victims among staff members of the American Army (Greenway and Harris, in Bunker, 2008:60). The security situation of these organizations is far more serious since, if the governments of the countries in which they are actively engaged cannot protect them; they are left at the mercy of the enemy. In such cases, these international organizations have to rely on private security companies and become their clients, together with many other international companies active in certain dangerous regions. In their inability to trust their safety in the hands of local governments on one side, and pressed by constant threats on the other, they choose to engage the services of private security companies. In certain cases, multilateral military forces, such as the UN, employ the services of private military companies to provide safety to their staff as a better alternative (Avant, in Williams, 2008:449).

- Due to changes in the nature of armed conflicts, many tasks that fell under the jurisdiction of armed forces became inadequate for modern armies, thus becoming more suited to private security companies. The staff of these companies is far better equipped for conducting operations in third world countries, and in Iraq their participation peaked. In 2003, a private security company, performing roles formerly performed by military personnel (trainings, logistics, operational support, etc), employed one in every ten US soldiers deployed to Iraqi bases... A large number of private security companies remained in Iraq even after the fall of the Iraqi government, employed by the interim allied government (for training of the Iraqi police and army, and securing the oil fields and government facilities), by the US army (for translations and interrogation of prisoners), or by a number of broadcasting, security, or non-governmental organizations (Avant, 2005). It is assumed that, around 21,000 employees of private military companies participated in the conflict in Iraq (Avant, 2012), and many reports point to the fact that they are numerous in conflicts in Africa, the Middle East, and other countries, where they provide military training and other military services.

- These are some of the most prominent moments that influenced the advance of private security, but what is notable is that this advance is real and is the response of the changes that occurred on a global scale around the turn of the $20^{\text {th }}$ century. In modern times, the role of private security services is completely different and much more important, whereas the main clients are countries and non-state actors. 


\section{Securiaty}

According to Singer (Singer, 2003:2), several hundred security companies are offering their services in over 100 countries worldwide. The spectrum of their services is considerable, both about external services (operational support, logistical support, counseling, and military training), as well as internal armed and unarmed security services, intelligence, crime prevention, etc. Avant (Avant, 2005:17) defines them as military and police services, and states that the most dangerous of them include armed operational support on the battlefield. However, not many contracts have been signed for such services, and companies offering them are not too transparent as to the activities they provide. Contracts offering and providing counseling and military training services, logistical and operational support regarding transport, system maintenance, and control, are much more common. The internal services provided by these companies coincide with the services provided by the state police, and the best known company that offers this type of services is DynCorp. Certain services, such as operational support in counter-insurgency, anti-terrorist and other special operations, are indicative of the lack of clarity of borders between internal and external security when it comes to international security threats, as well as of the necessity of combining police and military roles in such undefined areas (Andreas, 2003:78-111).

\section{Advantages and risks of private security services}

The privatization of security is undoubtedly a trend in the development of the concept of security in general, which inevitably brings it to the floor as a hot topic for debate. However, there still is a lot of ambiguity, obscurity, and skepticism regarding the positive role that private military companies play in international and regional security, as well as many controversial experiences with their involvement in many regions throughout the world. The possibilities that private security offers are nearly endless, but the security risks involved are not to be taken lightly. The services this sector provides can be useful for their client countries (provided these services are professional, well-regulated, and accountable), but they may also cause problems for the governments of those countries; and they may be an impediment on the road to democracy, long-term development, and peace-building processes in feebler countries, especially post-conflict countries (Vejnović, Pavlović, 2012:24).

The advantages of private security services over the state-organized security provided by the countries or international organizations are manifold. First, the recruitment and mobilization process in private military companies is fairly simple, fast and flexible, they do 


\section{Securiaty}

not need to maintain regular squads, but those squads can be readily mobilized in case of emergency or need. Usually they have a small number of employees, but a vast pool of potential candidates for mobilization on demand. They recruit on an international level, which is why they can always easily find the professionals they need for a specific action or operation. They are mostly persons with specific skill sets, most often retired army or police personnel, or personnel from special units. Taking into consideration the fact that the mobilization does not need to be approved by any political or other party, they can be readily engaged in action; and, when the action is completed, they can demobilize quickly and leave the territory in which they had acted (Avant, 2012). Secondly, private military companies are outside of any political, tribal, ethnic, or other interests, which are more often than not the causes for internal conflicts. They are not involved in political life and have no political motives because they work for profit; meaning, that they are solely led by personal interests, which motivates them to become engaged in a certain action or operation, without political strings attached. This could lead to a simplified conflict resolution process. Thirdly, the political price countries pay when they are hiring private security companies is lower than what they would pay should they engage their own armies. After the Cold War, the US cut down on military personnel due to political pressure, but used private military personnel for many different goals, with no political obligations (Avant, 2012). Engaging private armies in certain risky operations helps governments in situations when the political climate is hesitant to embark on such 'journeys', and especially so when there is no political or public approval for such actions. The public's sensitivity regarding the loss of human lives during armed operations outside national territory is increasing, but when that loss is on the side of the private security units, governments can control the flow of information regarding casualties under the belief that they will have fewer problems dealing with such unwanted consequences (Mandel, 2001:9). Furthermore, private security companies engaged in conflict regions and crisis areas are oftentimes more efficient than multinational forces, since they employ personnel with a wider range of specialties and skills, and have a greater degree of flexibility, which allows for a lower number of professionals to be engaged to staff a mission or operation (Avant, 2012).

Although many authors stress the advantages of private security services, and tend to build positive attitudes towards the advance of the private security sector, aiming to increase public acknowledgement, many authors dwell more on the perils stemming from the privatization of security. Potential threats are usually linked to the lack of control and legal regulation of this privatization, which brings the question of accountability and transparency of the private security companies to the surface. The existing legal limitations are most often ignored in some countries, and there is barely any interest in creating new legal framework for 


\section{Securiaty}

their action (Bunker, 2003:63). Although it is believed that that might have negative implications on the democratic processes in the regions where the private security companies have been actively engaged, as well as an on that country's control over the use of force, many authors believe that to be very unlikely. Private military companies are still limited in their actions by the governments who are hiring them, and by the nature of their work - which demands good relations to the people and control over their employees. For these companies, there is no good to be gained by operating in inadequate and inefficient methods, since that would ruin the reputation of the company (Howe, 1998, and Bunker, 2003:62). Shearer (Shearer, 1998:316) believes that private military companies can act pursuant to national and international interests and values, and at the same time, help the resolution of civilian conflicts by dealing with the 'dirty' interventions that the Western armies are trying to avoid. However, by establishing a legal framework, their work will gain legitimacy, greater professionalism and more value. Many subjects in the industry see defining global standards for action as a positive step forward in the efforts to establish rules and control that could prevent inefficiency and negative consequences. There is a lot of discussion surrounding this issue, but the biggest clients of the private security companies are concerned with the effects that these standards might have on flexibility and efficiency of the service providers, which is why they refuse to extend their support to and take part in these discussions (Avant, 2012).

The lack of transparency and accountability in the work of these companies is seen by some authors as an opportunity for their cooperation with international business interests (arms production and trade, exploitation of natural resources, etc), with authoritarian governments or military commanders in certain countries. Other potential threats include human rights violations, law violations, destabilization and militarization of the country, support for organized crime through involvement in the arms trade, and undermining the democratic processes (Fabien and Dearden, 2006:13-20). State security services in those countries are already not functional or competent, so the activities of the private security services would further subvert them, potentially creating a situation where private security services would be the only option the country has to protect itself and its citizens. Human rights abuses and inequality before the law are common in these situations (Pavlovic, 2011:11). In other cases, political exclusion from society turns them into convenient instruments for suppression and human rights violations, which infringes upon the national sovereignty of the country (Press release for the UN General Assembly Resolution, 1996).

The increased demand for the services of private military companies (in high-risk countries and regions, especially in the Iraq intervention) establishes a market ruled by the service provider, dictating a high price that also includes the price for security in dangerous 


\section{Securiatity}

and high-risk areas. Consequently, private military services not only fail to be a cheaper option, but could also be more expensive than the services provided by the state armies. The greater profit gained by the private security sector is also a threat to the state armies due to the overflow of personnel from the latter to the former. To cheapen the private option, and lower the costs, private companies are restricting the personnel and resources in performing certain tasks (such as engaging fewer professionals, or engaging personnel with lower qualifications and skill sets, etc), which results in a lower quality of services (Avant, 2012), which can put into question the efficiency and ultimate success of the action.

The ambiguous legal status of the members of the private military companies in the areas where they are active, as well as the unclear mechanisms for division of their rights and responsibilities, poses an issue for them and their cooperators. In case the government does not solicit their engagement (they are not working in government-backed operations), they face the risk of not having a legal status of combatants or prisoners of war, and being out of the military legal system, under threat of any consequence that stems from that.

The greatest dilemma regarding the effects of private security services is, however, linked to the legitimacy of the use of force for the protection of the country and its citizens. Global changes around the end of the $20^{\text {th }}$ century have also occasioned changes in the area of security (national and global security), and countries have increasingly transferred certain roles onto the private security sector. Even more accurately stated, the private security sector started to overtake certain roles that were under the jurisdiction of countries for ages before, thereby imposing itself as a new security actor on the international stage. The main questions remains: are countries losing their monopoly over the use of force, which is seen as the main factor in defining their sovereignty? It is obvious that the international, as well as the nonstate, financing of security diffuses the power over the control of the use of force, since other actors are participating in the decision-making process, apart from countries and their governments. However, this change in the role of countries in the use of force is not a challenge to the functioning of the country in the modern system, and it would be beneficial to look at it optimistically. Veber believes that in playing their part in security, other actors rely on the country and only the country has the power to a legitimate and legal use of force, which, in certain situations, might be entrusted in the hands of other actors (which is a sign of its democratic maturity). The country is the only party that decides to whom and under what conditions it would entrust the task of providing security. The country acts as a regulatory and supervisory body when it comes to the quality and legitimacy of the activities of the private security companies, regardless of how independent they are in performing their tasks (Veber, 1976,432 ). The privatization of security should be seen as a phenomenon indicative of the fact 


\section{Secuurity}

that countries acknowledge their limitations in guaranteeing the safety of their citizens when transferring some of their roles to private companies, although they do not fear losing the monopoly over these roles or the control of us of force (Avant, 2012). It is a fact that many feebler countries are using private security services to protect their citizens. In no way does that imply that private companies will grow stronger than the sovereign countries that hired their services, since their power is comparatively smaller to the national military forces, however weak they might be. Moreover, private companies do not sign contracts in a country without previous consent from that country, which means that these companies need to respect the conditions imposed by countries that hire and limit them from overuse of force.

In conclusion, the effects of the use of private security services on the power of the country using them depends in the highest degree on the power of that country to manage the risk of using their services on its territory. In that regard, the more powerful countries are leading and paving the way, whereas the frailer countries with inefficient, corrupt forces might face a unilateral dependency on private security services and a further weakening of their own military forces. This in turn decreases their power to control the use of force, increasing the possibility for illegitimate actions, which could further disturb the peace in that already unstable environment.

\section{Conclusion}

The enormous development of the private security sector was launched in the last decade of the $20^{\text {th }}$ century, when global changes made it possible security roles to be transferred to it from traditionally state-led security forces. This development is mostly owed to the increase in demand, as well as the supply, of private security services, caused in turn by the privatization processes in transition countries, the professionalization of state armies, the weak positions of many countries, and their non-functional governmental structures and army forces, the changes in the nature of armed conflict, the increased number of hostage incidents, violence, and mass murders in conflict regions where peace-building multi-national forces, humanitarian and other organizations are actively engaged. These are some of the factors that contributed to the development of traditional mercenaries into a modern private security industry, composed of companies with a fully developed corporate structure, relative openness and internationally acknowledged services.

Private security services draw great advantages in comparison to the services traditional state-led and multi-national armies offer. However, there are many dilemmas as to 


\section{Securiaty}

the effects of these services; mainly, (due to the lack of transparency and accountability of the private military companies), the high prices they charge, the lack of definition of the status of their employees in the area where they are actively engaged, and the lack of clarity when it comes to the division of rights and responsibilities. Whether the country is losing control over the use of force on its territory because of using the services of private security companies will only depend on that country's capacity to manage such risks and to direct private security services towards the common good. Regardless of any dilemma, the global demand for such services will continue to increase, leading to the necessity to legitimize these companies, and to make their staff liable to professional, ethical, and legal standards. It is only in this way that potential problems with uncontrolled privatization of security services could be avoided, simultaneously increasing the international acknowledgement of private security companies and their services.

\section{References}

1. Andreas, Peter. (2003): Redrawing Borders and Security in the $21^{\text {st }}$ Century, International Security, 28(2).

2. Avant, Deborah, D., (2005): The Market for Force: The Consequences of Privatizing Security, Cambridge: Cambridge University Press

3. Avant, Deborah, D., (2012): Private Military Companies and the Future of War, http://www.fpri.org/article/2012.

4. Bunker, Robert, J., (2003): Non-State Threats and Future Wars, Routledge.

5. Fabien, M., and Dearden, N., (2006): Corporate Mercenaries: The threat of private military and security companies, London: War on Want.

6. Mandel, R., (2001): The Privatization of Security, Armed Forces and Society Vol. 28 Issue 1, Chicago: Department of Political Science, Loyola University Chicago.

7. Pavlović, G., (2011): Pravo private bezbjednosti - uporedna studija, Banja Luka: Defendilogija centar.

8. Richards, A., Smith, H., (2007): Addressing the role of private security companies within security sector reform programmes, London: Saferworld.

9. Schreier, F., and Caparini, M., (2005): Privatizing Security: law, practice and governance of private military and security companies, Geneva: DCAF.

10. Shearer, David., (1998): Private Armies and Military Intervention, Oxford: Oxford University Press, Adelphi paper No. 316. 


\section{Seccurity}

11. Singer, P.W., (2003): Corporate Warriors: The Rise of the Privatized Military Industry, Ithaca, NY: Cornell University Press.

12. The Freedonia Group, (2012): World Security Services, Industry Study with Forecasts for 2016 and 2012, www.freedoniagroup.com.

13. Veber, M., (1976): Privreda I društvo - II knjiga, Beograd, Prosveta.

14. Vejnović, Duško, Pavlović, Gojko, (2010): Globalization and Privatization of Security, COBISS. BH - ID 1862936.

15. Williams, Paul, D., (2008): Security Studies: An Introduction, Routledge. 